Tóth Rita Noémi - Pólya Éva

\title{
A Tween szegmens fogyasztói magatartását befolyásoló tényezőinek és a reklámokkal szembeni attitűdjének vizsgálata Jász-Nagykun-Szolnok megyében
}

\author{
Tóth, Rita Noémi - Pólya, Éva \\ The Examination of the Factors Influencing the Tween Segment's Consumer \\ Behaviour and Attitude towards Advertisements \\ Összefoglaló \\ A fogyasztósszociológiai és reklámpszichológiai alapokon nyugvó téma jelentősége és aktualitása \\ több aspektusból is megközelíthetö. A gazdasági élet szereplöinek sikerült elérni, hogy a \\ fiatalkorúak az egyik legfontosabb célpiaccá „nőtték ki magukat”. Ugyanis napjainkban a \\ gyermekek és fiatalok a leginkább preferált célcsoport, ök a jövő (fogyasztói). Emellett egy olyan \\ fogyasztói társadalomban élünk, ahol a javak jellemzöen nem csupán a szükséglet-kielégítés \\ eszközei, hanem fontos befolyásoló tényezök is egyben, amelyek alapul szolgáltak a társadalmi \\ státuszkülönbségek kialakulásában. \\ Jelen munkánkban azt vizsgáljuk, hogy 2015-ben, a webkorszakban hogyan állnak a televiziós \\ reklámok tárgyköréhez a Z generáció tagjai, milyen attitüdökkel rendelkeznek; illetöleg ez \\ hogyan alakítja fogyasztói magatartásukat vagy mely tényezök azok, amelyek a mai kamaszokat \\ vásárlói döntésük meghozatalakor motiválnak. Ebböl adódóan célunk a Jász-Nagykun-Szolnok \\ megyében élő "tween” szegmens fogyasztási- és médiahasználati szokásainak, befolyásoló \\ tényezőinek, motívumaik, márkapriorizációik, illetve reklámokkal szembeni attitüdjeik \\ megvizsgálása.
}

Kulcsszavak: fogyasztói magatartás, pszichológia, reklám

\section{Abstract}

The importance and the relevance of the topic based on consumption psychology and advertising psychology can be approached from several aspects. The actors of business life managed to achieve that young people have become one of the most important target markets. Namely nowadays children and youngsters have been the most preferred target market, they are the future (consumers). Apart from this we live in a consumer society where goods are characteristically not only the tools of need fulfilment, but important influencing factors at the same time that form the basis of the formation of social status differences.

In our present paper we examine that in 2015 in the web age how members of generation $Z$ approach the subject of advertisements, what type of attitudes they have, and how these formulate their consumer behaviour or what are the motivating factors influencing nowadays' teens when a customer decision is made. Hence our aim is to examine the consumer and media usage behaviour, the influencing factors, the motives, brand priority and attitudes towards advertisements of the tween segment living in Jász-Nagykun-Szolnok County.

Key words: consumer behaviour, psychology, advertisement 


\section{SZAKIRODALMI ÁTTEKINTÉS}

\subsection{A FIATAL GYERMEK" - A SZEGMENS HATÁRAI}

A szegmens határainak pontosabb meghatározása érdekében célszerű a fogalom több szempontból való megközelítése. Munkánk során a Z generáció komplexitásából eredően, egyaránt használjuk a gyermek, tinédzser, éppúgy, mint a kamasz, fiatal, illetve fiatalkorú megnevezést; ugyanis - még a szakirodalom számára is - nehezen elválasztható fogalmakról van szó (Törőcsik, 2007).

Biológiai megközelítésben fontos életszakasz a gyerekkorból serdülőkorba való átmentet. A serdülőkorúak a biológiai érettség (12-14 éves kor) elérésének folyamatában vannak, ami a pubertást, a testi értelemben vett érést jelenti. Ez a kor az egyén személyiségfejlődésének egy újabb lépcsőfokát jelöli: a fiatal elkezdi kialakítani - szüleiétől függetlenedve -önálló véleményét, nézeteit, értékeit. A tinédzserek különösen a nyugati kultúrákban - erős késztetést éreznek arra, hogy „felnőttségüket” fogyasztási szokásaikon keresztül is kommunikálják, hiszen az anyagi javak birtoklása segíti az önkép és a presztízs kialakítását, ez sokszor már a külsőségekben (például az öltözködési szokásokban) megmutatkozik (Piacentini-Mailer, 2004).

Bizonyos szempontból a jog is szab határokat, melyeket a csoport irányba folytatott marketingtevékenységek kialakításakor érdemes fokozottan figyelembe venni. A hatályos, 2008. évi XLVIII törvény kimondja: „gyermekkorú az a személy, aki a tizennegyedik életévét nem töltötte be". Fiatalkorú az a személy, aki a tizennegyedik életévét betöltötte, de a tizennyolcadikat még nem (Reklámtörvény, 2008 [Online]).

A Z generációs gyermeki célcsoport mindezek mellett egy komoly életkori szegmenst jelöl. Az életkorral összefüggésben számos olyan esemény következik be, amelyek a célcsoport jellemzőit alakítják. Bizonyos élettapasztalatok megléte vagy hiánya segítséget nyújthat a fiatalkor határainak árnyaltabb meghatározásában. Ezek összefüggő történések részei, sorrendjük egyénenként eltérő. Jean Piaget konstruktivista elméletét megalkotva, azt vizsgálta, hogy a gyerekek hogyan ismerik meg a világot és hogyan válnak képessé hatékony cselekvésre. $\mathrm{Az}$ általa kialakított szakaszokat a gyermek- és fiatalkorúak kognitív, mentális képességei alapján határozta meg. Ezek, a Z generáció fogyasztási szokásait alakító (tapasztalat, szocializáció, genetikus adottságok) szempontból, legfontosabb szakaszok a következők (Cole-Cole, 2003):

- Múveletek előtti szakasz (3-6 éves korig): Ebben a korban a gyerekek a világot saját szempontjukból értelmezik. A gyermek szókincse gyarapszik, képesek a valóságot szimbólumok, szavak és gesztusok segítségével leképezni. Ezen szakaszban az intelligencia és kognitív képességek gyorsan fejlődnek, azonban még sokszor összekeverik az oksági viszonyokat. Nem látják át, nem értik pontosan az összetett kapcsolatokat, ezért többnyire tényként kezelik a számukra mondott információt. A hiszékenységük miatt különösen kiszolgáltatottak ebben a korban a reklámok káros üzeneteinek.

- Konkrét múveleti szakasz (6-12 éves korig): A gyermeket a logikai rendszerbe illő gondolkodás jellemzi, képesek a tárgyaknak egyszerre több tulajdonságát is figyelembe venni; valamint egy probléma két lehetséges megoldását képesek már összehasonlítani. Ekkor már csökken az egocentrizmus, el tudják képzelni azt, hogy mások miként látják őket, ami nagy hatást gyakorol arra, hogy milyen termékeket fogyasztanak. Ebben a korban hatással vannak rájuk a termékeken megjelenített mesefigurák, logók, színek, és karakterek, továbbá kialakítható az egyes márkákhoz való kötődés. Viszont egyelőre még nem 
érzékeli a márkával azonosított termék és a márka önmaga közti különbséget.

- Formális múveleti szakasz (12 éves kor fölött): A gyermek képes logikai elemzésekre, egy problémán belül képessé válik minden logikai kapcsolatot végiggondolására. Ebben a korban már érdeklődést mutatnak elvont eszmék- és magának a gondolkodás folyamatának a megismerésére. Továbbá ez az a szakasz, amiben a jövőt, mint az idő dimenzióját felfedezik.

\section{2. „TWEEN”KORCSOPORT}

$\mathrm{Az}$ életkor tekintetében marketinges jellegzetesség a „Tween” szó használata. A korábban már említett, sajátos életkori elnevezés egy, a nemzetközi szakirodalom által használt aktuális megközelítés létrejötte a külföldi marketingszakembereknek köszönhető. Mivel korábban a marketing szakirodalomban nem született konszenzus arra vonatkozóan, hogy életkor szerint kik tartoznak a gyermekek, kamaszok vagy a fiatalok korosztályába, megalkották a „Tween” kategóriáját a nagy lélekszámú, fiatal piac könnyebb lehatárolása érdekében. $\mathrm{Az}$ összeforrt fogalom az angol between /között/ és teen /tizenéves/ szavak egybeolvadásával jött létre. A „Tween” egészen pontosan a 8-14 éves, a gyermekkor a fiatalkor választópontján levő fiatalkorúakat jelöli, akik a már nem kisgyermekek, de még nem is fiatal felnőttek. (Crowley et al., 2014 [Online]). Ők a fiatal gyermekek.

Beigazolódott, hogy a legfiatalabb generáció valóban összetett; megértésük egy komplex folyamat eredmény függvénye. Vállalati- és marketing oldalról megközelítve a gyermek- és fiatalkorúak csoportja a „jövő reménységei”, éppen ezért viselkedésük, fogyasztói magatartásuk megismerésére, megértésére számos szakember keresi a választ.

\section{ANYAG ÉS MÓDSZERTAN}

Kutatásunk során alapvetően kvantitatív kutatási technikát alkalmaztunk. Lényegében ellentmondásos a legösszetettebb gyermeki érzéseket, véleményeket adatokban kifejezni, számszerúsíteni, azonban kérdőíves lekérdezés során mégis kísérletet tettünk ezek megismerésére. Személyes megkérdezés keretei közt, kismintás próbalekérdezés végrehajtása után, papír alapon 967 kérdőív kitöltése valósult meg 2014 januárja és 2014 októbere között, reprezentativitásra törekedve; ebből azonban 55 kérdőív kiértékelhetetlennek minősült.

A kérdőív összeállításakor egyaránt alkalmaztunk nyitott és strukturált kérdéseket. Utóbbiak között használtunk szelektív zárt és alternatív zárt kérdéseket, rangsort, valamint 4, 5 fokozatú Likert-skálát. A kérdőíves lekérdezés három, módszertanilag lényegében azonos kérdéscsoportokat foglal magába: a motiváció- (miért?), attitűd- (mennyire?) és imázs-kutatást (milyen?). Így az összeállított kérdések elsősorban a mintában résztvevők fogyasztói magatartását befolyásoló tényezőit kutatják. A szekunder kutatásból következően az alapsokaság a tudatos kiválasztás elvének megfelelően a 10 és 14 éves korosztály tagjaira esett, őket választottam kutatásom célcsoportjául. A mintába kerülés során a többlépcsős kiválasztás elve érvényesült, először a várost, ezt követően az iskolákat.

A válaszadók arányát tekintve 51 százalékuk fiú, 49 százalékuk pedig lány volt. A kutatásban érdemben 912 fő fiatalkorú vett részt. A KSH mikrocenzus népességadatai alapján $Z$ próba segítségével reprezentativitás vizsgálatot végeztünk a mintán, amelynek eredményeképpen 5\%-os szignifikancia szinten az reprezentatívnak tekinthető /Isd. XII. számú melléklet/.

A kutatás Jász-Nagykun Szolnok megyét helyezi középpontba. Az itt élő Tween korosztály fogyasztási- és médiahasználati szokásait, motiváltságukat, márkapreferenciájukat és az őket befolyásoló reklámokkal kapcsolatos attitúdjeiket. Kutatásunk területi lehatároltságát egyrészt a költség-hasznon alapelv, másrészt az a tény magyarázza, hogy a 
fiatalkorúak fogyasztási szerkezetét nem befolyásolja jelentősen az országon belüli térbeli elhelyezkedés. Ezt igazolja Szúcs (2011) hasonló témakörben lefolytatott kutatása is.

$\mathrm{Az}$ adatok feldolgozása során matematikai, statisztikai módszereket alkalmaztunk (átlag, módusz, medián, szórás, kereszttábla vizsgálatok, Cramer-féle asszociációs vizsgálat,

Kendall-féle egyetértési együttható, K-means klaszterelemzés, stb.) SPSS 20.0 és Microsoft Excel 2010 programok segítségével.

\subsection{A MINTA ÖSSZETÉTELE}

Már a Z-próba elvégzése során megfigyelhető volt, hogy a mintán belül a nemek közti arány közel azonos értéket mutat - a megyei átlagos adathoz hasonlóan - a fiúk javára (51\%). A megkérdezettek kor szerinti megoszlása hasonló a 11 (27\%), 12 (23\%), illetve 13 évesek $(22,7 \%)$ körében, a legkevesebben a 10 évesek közül töltötték ki a kérdőívet. Míg a 10-11-13 évesek többsége fiú, addig a 12, illetve 14 éves korcsoportban a lányok képviselnek döntő többséget. Ezt az alábbi táblázat szemlélteti:

A minta nem és kor szerinti összetétele

1. táblázat

\begin{tabular}{|l|r|r|r|r|r|r|}
\hline & \multicolumn{7}{|c|}{ Nem } \\
\cline { 2 - 8 } & \multicolumn{2}{|c|}{ Fiú } & \multicolumn{2}{c|}{ Lány } & \multicolumn{2}{c|}{ Összesen } \\
\hline \multirow{2}{*}{ Életkor } & $\begin{array}{l}\text { Részvevő́k } \\
\text { száma (fő) }\end{array}$ & $\begin{array}{c}\text { Megoszlás } \\
\text { (\%) }\end{array}$ & $\begin{array}{c}\text { Résztvevők } \\
\text { száma (fö) }\end{array}$ & $\begin{array}{c}\text { Megoszlás } \\
\text { (\%) }\end{array}$ & $\begin{array}{c}\text { Résztvevők } \\
\text { száma (fö) }\end{array}$ & $\begin{array}{c}\text { Megoszlás } \\
\text { (\%) }\end{array}$ \\
\hline $\mathbf{1 0}$ év & 51 & 5,6 & 30 & 3,3 & $\mathbf{8 1}$ & $\mathbf{8 , 9}$ \\
\hline $\mathbf{1 1}$ év & 129 & 14,1 & 117 & 12,8 & $\mathbf{2 4 6}$ & $\mathbf{2 7}$ \\
\hline $\mathbf{1 2}$ év & 96 & 10,5 & 114 & 12,5 & $\mathbf{2 1 0}$ & $\mathbf{2 3}$ \\
\hline $\mathbf{1 3}$ év & 114 & 12,5 & 93 & 10,2 & $\mathbf{2 0 7}$ & $\mathbf{2 2 , 7}$ \\
\hline $\mathbf{1 4}$ év & 78 & 8,6 & 90 & 9,9 & $\mathbf{1 6 8}$ & $\mathbf{1 8 , 4}$ \\
\hline Összesen & $\mathbf{4 6 8}$ & $\mathbf{5 1 , 3}$ & $\mathbf{4 4 4}$ & $\mathbf{4 8 , 7}$ & $\mathbf{9 1 2}$ & $\mathbf{1 0 0}$ \\
\hline
\end{tabular}

\section{1. ábra. A fiatalokat jellemző szabadidő eltöltési szokások}

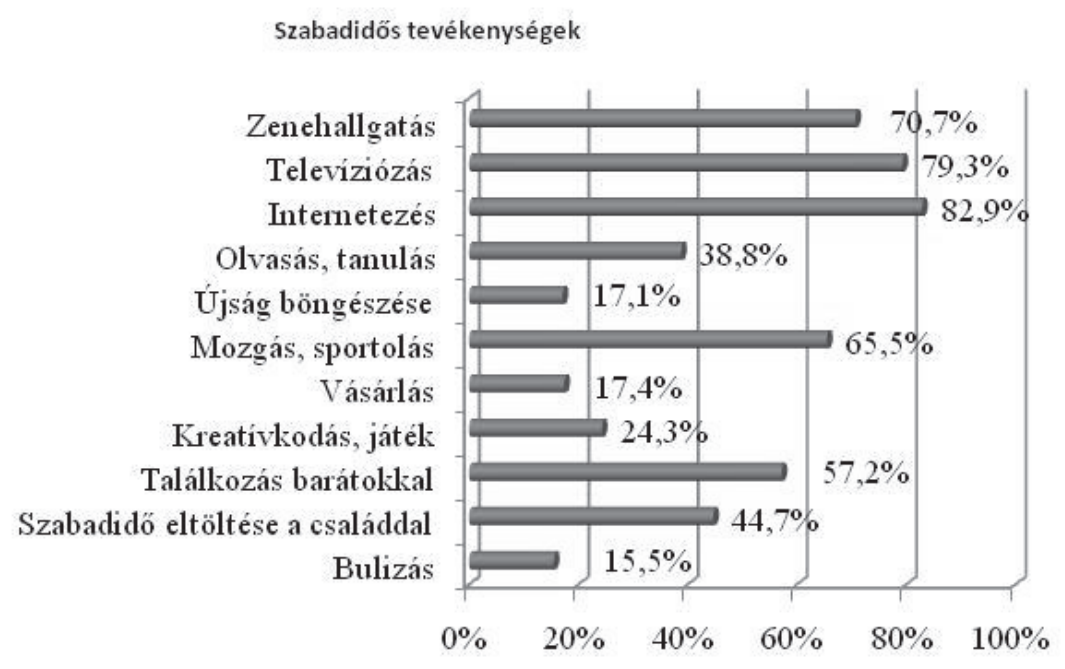

Forrás: Saját kutatás 
A válaszadók lakóhelyét tekintve nem jellemző erőteljes megosztottság; a megkérdezettek több, mint közel háromnegyede (79\%) lakik a megyeszékhelyen (Szolnok) és annak vonzáskörzetében (Szandaszőlős, Rákóczifalva, Tószeg, Zagyvarékas, Újszász, Martfű), mely tényező hasonló színvonalú életkörülményeket feltételez.

Így a lakhely a továbbiakban nem képezi összehasonlítás alapját. A fennmaradó 21\% válaszai Törökszentmiklós és Jászberény városokból érkeztek.

\section{EREDMÉNYEK}

\subsection{A KORCSOPORT ÁLTALÁNOS FOGYASZTÓI JELLEMZŐI}

A digitalizáció évtizedekkel ezelőtt magával hozta az egyes szabadidős tevékenységek alapjaiban való átalakulását. Az évek előrehaladtával a felgyorsult életritmus és az információs technológia robbanásszerú fejlődésének okán első lépésben azt vizsgáltuk, hogy általánosságban milyen szabadidő eltöltési szokások jellemzik az általunk megkérdezett 1014 éves korosztályt, ezt szemlélteti az 1. számú ábra.

$\mathrm{Az}$ internet térhódítása figyelemre méltó, ugyanis a megkérdezettek körében - a szakirodalmi áttekintés során megismert kutatási adatokkal ellentétben - a leggyakoribb szabadidős tevékenységnek az internetezés $(82,9 \%)$ bizonyult, csak ezt követte 2 . helyen a televíziózással eltöltött idő (79,3\%). Az iskolások jelentős arányban fordították továbbá szabadidejüket zenehallgatásra $(70,7 \%)$, illetve sportolásra (65,50\%). Utóbbi meglepő adat, hiszen számos kutatás számol be arról, hogy a gyerekek többsége nem fordít kellő figyelmet a rendszeres testmozgásra, aminek okán - a helytelen táplálkozással kiegészülve - már köreikben is gyakori a túlsúllyal rendelkező krónikus betegek aránya. Az ábrán az is jól látható, hogy a fiatalok nem hanyagolják el társas kapcsolataikat sem; hiszen a megkérdezettek több, mint fele $(57,2 \%)$ szívesen találkozik barátaival szabadidejében és emellett a családdal együtt töltött időre is kellő figyelmet fordít $(44,7 \%)$. A webkorszakban összességében az intellektuális tevékenységek mint az olvasás, a kreatív folyamatok és különféle játékok - valamint a vásárlás mindmind háttérbe szorulnak. Az „egyéb” válaszlehetőségen belül háziállattal való elfoglaltságot, színházat, hangszeren való játékot, illetve motorozást említettek kiegészítésképpen. Érthetően szórakozni járnak el a legritkábban az általános iskolások (15,5\%), ez közülük is inkább a 13-14 éves korosztályra jellemző. Ezen tényezőt leszámítva, korcsoportonként nem tapasztalhatók éles eltérések. Nemek tekintetében, míg a lányok inkább a tipikusan női elfoglaltságnak számító olvasást, kézimunkázást, magazinok lapozgatását, vásárlást, illetve a barátokkal és a családdal való szabadidő eltöltést preferálják, addig a fiúk a gyengébbik nemnél nagyobb arányban interneteznek, tévéznek, sportolnak és hallgatnak zenét.

Mint fogyasztási tényezőt, szükségét éreztük felmérni, hogy milyen médiahasználati szokások jellemzik a vizsgált korosztályt a két legnépszerübb kommunikációs csatorna tekintetében. Az összesített válaszok alapján elmondható, hogy az iskolások hétköznapi és hétvégi televízió nézési-, illetve internetezési ideje a szabadidő eltöltésére irányuló kérdésre érkezett válaszokkal szemben ellentmondásosan alakult. Eszerint míg a fiatalok hétköznap átlagosan 2,52 órát, hétvégén 3,28 órát fordítanak internetezésre, addig ugyanez az arány a televíziózás esetében hétköznap átlagosan 2,7 órát, hétvégén pedig 3,37 órát jelent. Tehát a megkérdezettek - a közép-kelet-európai viszonyokhoz húen továbbra is több időt töltenek el a tévé képernyője előtt (Isd. bővebben IX. számú melléklet). Általánosságban elmondható, hogy nemtől és korcsoporttól függetlenül a hétvégi napokon a televízió és az internethasználat aránya magasabb, mint hétköznapokon. Az iskolások elsősorban zenehallgatásra $(75,3 \%)$, chatelésre $(69,1 \%)$ és játékra $(58,6 \%)$ használják az internetet, ami egyben a tanulók több, mint felének $(51,6 \%)$ a házi feladat megírását segítő 
eszközként is funkcionál. Az egyes korcsoportok és a két médium használatának gyakorisága között lineáris kapcsolat figyelhető meg, ugyanis a kor elörehaladtával mind az internethasználat, mind a televíziózás gyakorisága egyenes arányban nő.

A fiatalok „médiafogyasztásáról” szerzett beható képet követően tényleges fogyasztási (vásárlói) oldalról folytatom a megkérdezett 1014 éves korosztály jellemzőinek feltérképezését. A vásárlói szokások vizsgálata előtt érdemes közelebbről megismerni a Tween korosztály vásárlóerejét. A megkérdezett iskolások csaknem fele $(46,1 \%)$ havi szinten 1000-5000 Ft értékű összegből gazdálkodik, amely döntő többségében (73,7\%) a szülők diszkrecionális jövedelmének egy részét képezi vagy különleges alkalmaknak köszönhetően más rokonoktól származik. Emellett számos háztartásban (17,4\%) a gyermek az otthon végzett munkálatokért cserébe vagy iskolai teljesítménye alapján kap juttatást. A havi átlagos zsebpénz a 13-14 évesek körében a legmagasabb, ők 5000-10.000 Ft felett rendelkeznek szabadon minden hónapban. A válaszadók mindösszesen 8,9 százalékának nincs költőpénze, ők állításuk szerint a családdal vásárolnak. Megvizsgálva, hogy van-e összefüggés az egy hónapra eső nettó zsebpénz és az életkor között a Cramer-féle mutató 0,138-as értéke gyenge kapcsolatra utal (Isd. bővebben X. számú melléklet).

A vizsgált korosztály zsebpénz-elköltésére vonatkozó szokásait a következő 2 . ábra szemlélteti. Az ábrán megfigyelhető, hogy a saját pénzzel rendelkező iskolások által adott válaszok száma az egyes kategóriákat tekintve relatíve alacsony.

Ez azzal magyarázható, hogy a megkérdezettek több, mint fele $(54,1 \%)$ racionálisan kezeli a rendelkezésére álló havi költőpénzét - spórol. Különösen igaz ez a fiúkat illetően, akik takarékosabbak lány társaiknál. A 2. ábra azt is jól illusztrálja, hogy a gyerekek összességében élelmiszerre (73\%) költenek a legtöbbet. Ezt követik a ruhanemúre $(45,6 \%)$, nassolnivalókra
(37,4\%), könyvekre és magazinokra (31\%), valamint szórakozásra fordított kiadások. Ugyan a kapcsolat szorosságát mutató Cramer's V érték egyik tényező esetében sem jelez szignifikáns kapcsolatot a nem, illetve a kor viszonylatában (Isd. bővebben X. számú melléklet), a legtöbb esetben mégis szembetűnő a nemi szerepekhez kapcsolódó fogyasztás. Ez, lányoknál a kiegészítők, kozmetikumok és különféle szolgáltatások-, a fiúk esetében pedig az elektronikai cikkek, sportfelszerelések és játékok vásárlásánál mutatkozik meg.

A gyerekek önálló fogyasztási döntései mellett, kortól és nemtől függetlenül, a megkérdezettek 67,1\%-a jelentős indirekt szereppel bír a családi vásárlások során. A válaszadók $32,6 \%$-a saját véleményének közvetett szerepét jelölte meg a család által vásárolt, rejtett és luxus fogyasztási cikkekre vonatkozóan. Mindösszesen 3 fó válaszolta, hogy szülei egyáltalán nem veszik figyelembe véleményét az egyes vásárlások alkalmával. Vizsgálva, hogy milyen kapcsolat van a kor és a nem, illetve a megkérdezettek családi vásárlásokban betöltött szerepe között, a Cramer-féle mutató értéke $(V=0,140$ és $V=$ 0,068 ) egyik esetben sem jelöl szignifikáns kapcsolatot.

Ahogyan az az elméleti fejezetben bemutatásra került a Z generáció életstílusával, kedvenc márkáival, zenéivel, médiahasználati szokásaival meghatározó preferenciák mentén fogyaszt. $\mathrm{Az}$ értékrend nagymértékben meghatározza az emberek életstílusát, magatartását, így azok fogyasztói magatartását, termék- vagy márkaválasztását is. Ezért fontosnak tartottuk megvizsgálni, hogy az iskolások számára mely tényezők jelentik a legfontosabb értékeket. Kahle List of Values alapötletét adaptálva összeállítottunk egy értéklistát, amely alapján a fiatalok értékítéleteit tanulmányozni tudjuk. Ezek az életmód kialakításához kapcsolható, a mindennapi életben jelen levő értékek ( $8 \mathrm{db}$ ) legfóképpen önmagukra és az interperszonális kapcsolatokra irányulnak. 
Kahle módszerét áttranszformálva arra kértük a fiatalokat, hogy rendezzék sorrendbe ezen értékeket növekvő preferencia szerint. Az így felállított rangsort az 2. táblázat foglalja magában.

\section{2. ábra. A havi rendelkezésre álló zsebpénz elköltésének módjai}

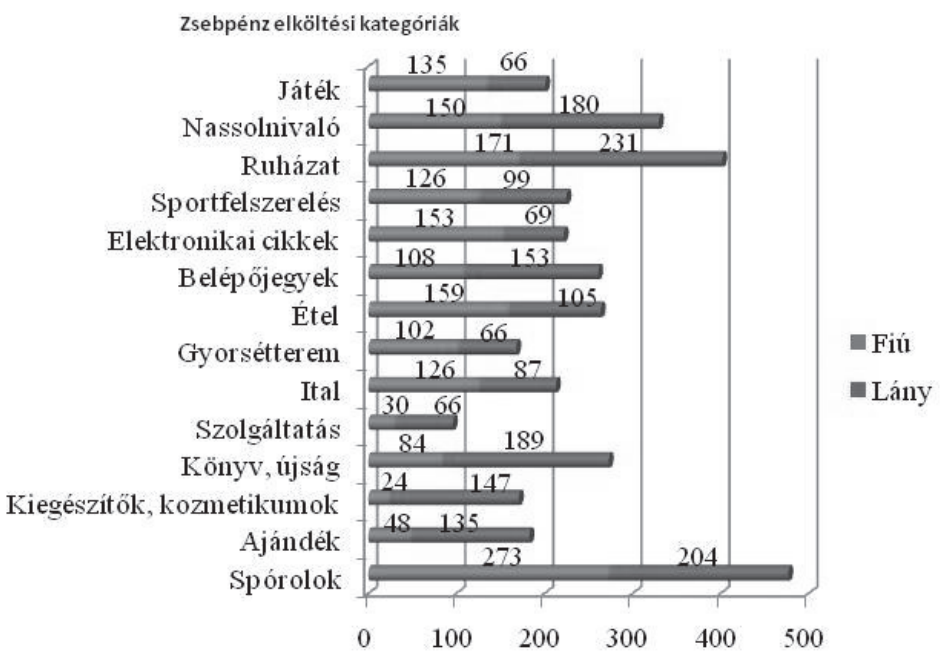

Forrás: Saját kutatás

\section{A megkérdezettek által felállított értéklista}

\begin{tabular}{|c|c|c|c|c|c|c|c|c|c|c|}
\hline \multirow[b]{2}{*}{ Értékjellemzők } & \multicolumn{8}{|c|}{ Fontossági sorrend 1-8-ig* } & \multirow[b]{2}{*}{ Sum } & \multirow{2}{*}{$\begin{array}{c}\text { Felállítot } \\
\mathbf{t} \\
\text { rangsor }\end{array}$} \\
\hline & 1 & 2 & 3 & 4 & 5 & 6 & 7 & 8 & & \\
\hline Gyorsaság & 48 & 39 & 42 & 108 & 129 & 168 & 126 & $\begin{array}{r}25 \\
2\end{array}$ & $\begin{array}{r}523 \\
5\end{array}$ & 7 \\
\hline Szabadság & 195 & 171 & 114 & 132 & 123 & 93 & 60 & 24 & $\begin{array}{r}319 \\
2\end{array}$ & 2 \\
\hline Önmegismerés & 81 & 129 & 195 & 144 & 108 & 81 & 99 & 75 & $\begin{array}{r}381 \\
9\end{array}$ & 4 \\
\hline Egyediség & 72 & 117 & 153 & 156 & 150 & 120 & 85 & 60 & $\begin{array}{r}392 \\
7 \\
\end{array}$ & 5 \\
\hline $\begin{array}{l}\text { Valahová } \\
\text { tartozás }\end{array}$ & 171 & 162 & 126 & 153 & 108 & 78 & 54 & 60 & $\begin{array}{c}335 \\
1\end{array}$ & 3 \\
\hline $\begin{array}{l}\text { Divat, } \\
\text { szórakozás }\end{array}$ & 51 & 57 & 66 & 69 & 69 & 150 & 222 & $\begin{array}{r}22 \\
5\end{array}$ & $\begin{array}{r}526 \\
5 \\
\end{array}$ & 8 \\
\hline Biztonság & 246 & 168 & 150 & 84 & 111 & 72 & 54 & 27 & $\begin{array}{r}294 \\
9\end{array}$ & 1 \\
\hline Szépség & 51 & 75 & 69 & 63 & 120 & 144 & 207 & $\begin{array}{r}18 \\
3\end{array}$ & $\begin{array}{r}503 \\
7\end{array}$ & 6 \\
\hline
\end{tabular}

* Ahol 1 - a legfontosabb és 8 - a legkevésbé fontos 
Minél kisebb a táblázatban feltüntetett, fontossággal súlyozott érték, annál fontosabb az egyes állítás. Tehát a legkisebb számérték a legfontosabb, a legnagyobb pedig a legkevésbé fontos. Ez alapján a következő sorrend állt fel: biztonság, szabadság, valahová tartozás, önmegismerés, egyediség, szépség, gyorsaság, divat és szórakozás.

Egy másik megközelítés, hogy a válaszadók által legfontosabbnak (1.) ítélt oszlop elemeit sorba rendeztük. Így - a megadott válaszok alapján legfontosabb tényezők mentén átlagosan a következő rangsor állítható fel: biztonság, szabadság, valahová tartozás, önmegismerés, egyediség, szépség, divat és szórakozás, gyorsaság. Látható, hogy a felállított rangsorok pusztán az utolsó 2 érték esetében térnek el, amely a válaszadók alacsony egyetértési hajlandóságával magyarázható (Isd. 65.o.).

Az összesített válaszok alapján egyöntetúen a környezeti és az interperszonális értékékek, úgy, mint a biztonság, a szabadság és valahova tartozás játszanak életükben központi szerepet. Ebből életstílusukra vonatkozóan megállapítható, hogy szükségük van a stabilitásra, mind anyagi, mind szellemi, mind pedig szociális téren, ugyanakkor emellett vágynak a korlátoktól való mentességre önmaguk megvalósítása érdekében. Jól látható az is, hogy míg törekednek a szülőktől való függetlenedésre, addig a közösséghez kötődő értékek marginális szerepet kapnak, fontos számukra társaik elismerése. Kendall-féle egyetértési együttható segítségével megvizsgálható, hogy a kialakult válaszok között mekkora az általános egyetértési szint. Az így számított W érték a 912 megkérdezett tekintetében 0,453 , amely szerint a válaszadók 45,3\%-a teljes egészében egyetért a kialakult sorrenddel és értékekkel. A fennmaradó $54,7 \%$ véleményének különbözősége az egyes korcsoportok összetettségével magyarázható.

$\mathrm{Az}$ értékítéletekkel összefüggésben nyílt kérdésben arról kérdeztük a kitöltőket, hogy kit tekintenek példaképüknek. A fiatalok példaképválasztása ugyanis arról árulkodik, hogy milyen egyéni, erkölcsi és kompetenciaértékeket tartanak fontosnak, milyen értékrenddel rendelkeznek. A válaszadók közel 45 százaléka nem adott releváns választ a kérdésre - vagy azért mert nem tudott vagy nem akart válaszolni. A legnagyobb arányban (külföldi) médiaszereplők inspirálják őket - különösen az idősebb korosztályt- úgy, mint színészek, sportolók, énekesek, celebek, modellek, írók, de említették még Mark Zuckerberget, Kalkuttai Teréz anyát és a dalai lámát is. A fiatalabbak inkább a családból, illetve közvetlen ismertségi körökből választottak maguknak példaképet. Ez arra utal, hogy míg a fiatalabb korosztály esetében a személyes értékek a fontosak, addig az idősebbek esetében inkább a külsőségek dominálnak.

Egy újabb nyílt kérdés a megkérdezett 10-14 évesek jövőképére irányult. Arra kértük őket, hogy nevezzenek meg egy olyan hivatást, amivel szívesen foglalkoznának a jövőben. A Wordle Create $^{\mathrm{TM}}$ segítségével egy szófelhőt készítettünk a leggyakoribb válaszokról, ezt szemlélteti a 3. ábra

\section{3. ábra. A megkérdezettek által preferált foglalkozások}

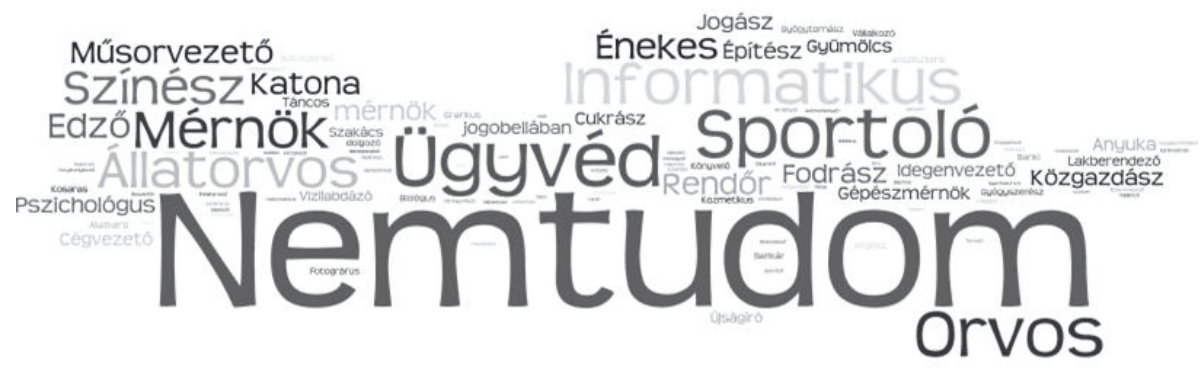

Forrás: Saját kutatás 
Ambiciózusak és karrieristák. Azon kevesek, akik tudják, mivé szeretnének lenni. Az esetek többségében egyrészt populáris és magas presztízzsel rendelkező szakmákat, pl. ügyvéd, orvos, mérnök, informatikus, pszichológus, közgazdász; másrészt tisztességes és becsületes foglalkozásokat neveztek meg, mint például sportoló, edző, katona, fodrász, masszőz és anyuka. Szembetúnő, hogy a "hagyományos" foglalkozások mellett akadtak olyanok, akik a média által felépített, „könnyebbik utat” választanák a siker és hírnév elérésére, ők színészi, músorvezetői ambíciókkal rendelkeznek. Ezenkívül volt olyan válaszadó is, aki egész egyszerúen felnőtt szeretne lenni vagy a reklámból eredeztethetően „gyümölcs a Jogobellában".

Miután tinédzser korban a fogyasztás a szükségletkielégítés mellett egyre inkább egyénivé és az önkifejezés formájává kezd válni, a márkák a szimbolikus fogyasztás legkézenfekvőbb eszközei. Ehhez kapcsolódóan egyrészt márkapreferenciáikról kérdeztük a fiatalokat, ezt szemlélteti a 4. ábra

\section{4. ábra. Az egyes korcsoportok márkaprioritása}

\section{Márkaprioritás}

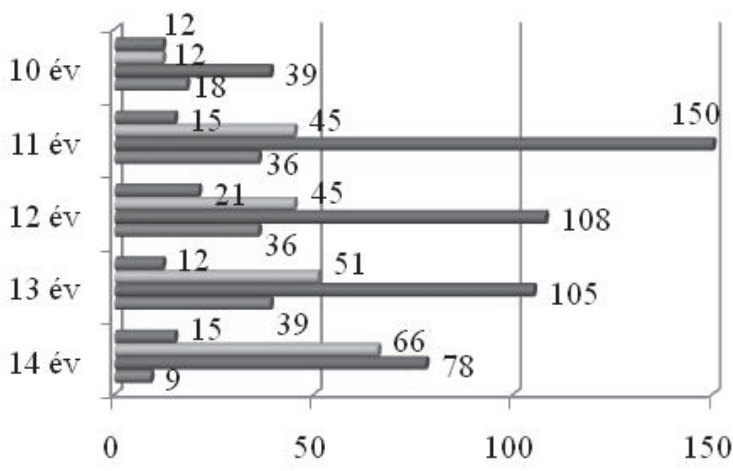

Nagyon fontos, ragaszkodom a márkához Fontos

- Kevésbé fontos, időnként mást választok

Egyáltalán nem fontos, sokszor választok más terméket

Forrás: Saját kutatás

A válaszadók többségének (52,6\%) kevésbé fontos a márkatermék-vásárlás. Mindösszesen 8,2\%-uk vallja magát elkötelezettnek a márkák iránt, ők leginkább a 12 évesek köreiből kerültek ki és jellemzően fiúk. Noha a Cramerféle mutató nem állapított meg szoros kapcsolatot sem az egyes korcsoportok ( $\mathrm{V}=$ $0,138)$, sem pedig a nemek esetében $(V=$ 0,191), általánosan megfigyelhető tendencia, hogy a márkatermék-vásárlás legkevésbé a 1011 éves korosztály esetében fontos, nem ragaszkodnak szükségszerúen a márkákhoz (Isd. bővebben XI. számú melléklet). Ez azt támasztja alá, hogy még szükségleteik, ízlésviláguk folyamatosan változó, ezáltal még márkapreferenciáik is formálhatóak. Nincsenek „saját márkáik”, helyettük fogyasztói attitűdjeik az idősebbektől adoptált márkák interiorizálásával jellemezhető. Ennek okán releváns a vállalatok szempontjából, hogy még a korai időszakban, milyen kapcsolatot sikerül létrehozni a gyerek és a márka között, ahogyan az is, hogy különös figyelmet fordítsanak annak elvárásaira, döntési szempontjaira annak érdekében, hogy a későbbiekben minél hatékonyabban megszólíthatók legyenek.

A vállalatok ezen törekvéseinek eredményességét vizsgálva arra kértük a kérdőivet kitöltőket, hogy kategorizálják magukat aszerint, hogy hány olyan márkanevet tudnak felsorolni, amelyet rendszeresen vásárolnak. A válaszként adott számok arról árulkodnak, hogy mennyire hüségesek egy-egy márkához. Így értelemszerūen minél kevesebb 
márkát vásárolnak rendszeresen, annál hűségesebbnek mondhatók. A Cramer mutató értékei a kor viszonylatában $V=0,136$, nemek tekintetében pedig $\mathrm{V}=0,150$, ez nem feltételez szignifikáns kapcsolatot. Ugyanakkor a számadatok tekintetében kivehetők jól látható különbségek mind a fiúkra és lányokra, mind pedig az egyes korcsoportokra vonatkozóan. A válaszadók közel 40\%-a húséges egy-egy, számára már bevált márkához, ők fóként a 1314 évesek köreiből kerülnek ki és többségében lányok. A fiúk összességében több márkanevet tudnának felsorolni, amelyet rendszeresen használnak, ezért náluk kevésbé jellemző, hogy egy már jól bevált márkához ragaszkodjanak. A megkérdezettek mindösszesen 8,6\%-a - kortól és nemtől függetlenül - nem ragaszkodik a rendszeres márkatermék-vásárláshoz.

Márkapreferenciáikról

összességében elmondható, hogy a kor előrehaladtával az egyes márkatermék-priorizációjuk és emellett márkatudatosságuk fokozódik, vagyis a márkakommunikáció (PoS és PoP eszközök, hirdetések, egyéb márkapromóciók) eredményesnek bizonyul az általunk vizsgált 1014 évesek körében.

Így a márkák egyrészt számukra a szimbolikus fogyasztás eszközei, másrészt pedig a vállalatok eszközei a hűségre való nevelésre.

\subsection{A FOGYASZTÓI MAGATARTÁST BEFOLYÁSOLÓ TÉNYEZŐK}

$A z$ egyéni tényezők értelmezése önmagában nem elegendő a célpiac megismerésére; össze kell kapcsolni a fogyasztást befolyásoló tényezőkkel. Ezért a fogyasztáshoz való viszonyuk bemutatása után a következőkben a megkérdezettek vásárlását motiváló, illetve fogyasztását befolyásoló külső tényezők elemzése a célunk. Száz százalékos garancia semmire nincs, ahogyan arra se, hogy minden gyermek esetében ugyanazok a változók figyelembe vétele a fontos, de a célcsoport általánosságban megismerhetőbbé érthetőbbé válik ezen ismérvek mentén.
A fogyasztást a szükségletek motiválják, az egyén értékrendszerét követve. Első lépésként annak felkutatása volt a célunk, hogy milyen hajtóerők aktivizálják az általam vizsgált 10-14 éves korosztály magatartását vásárlási döntéseik során. Ezért arról kérdeztük az iskolásokat, hogy melyek azok a személyes motivációik, amelyek egy termék megvásárlásánál döntő szerepet játszanak.

Kutatásunk ezen kérdésének megszerkesztésekor tudatossággal, tetszóleges kiválasztott, a marketingkommunikáció eredményességét vizsgáló válaszlehetőségeket használtuk. A beérkezett válaszok feldolgozása során hamar kiderült, hogy a kérdőívet kitöltők felismerték a kérdés ravaszságát, ezért „egyéb” válaszlehetőségként valódi személyes késztetéseket, tényleges motivációikat jelölték meg, előzetes reményeinknek megfelelően.

Saját elmondásuk szerint termékvásárláskor a döntő szempontot a megvásárolandó termék minősége jelenti. A legfontosabb preferenciaszempontok közé tartoznak továbbá az elsődleges (pl. íz, illat, funkció, tartósság, stílus) és másodlagos (csomagolás, design, márka) termékjellemzők, ahogyan a termék ára is.

Fontos, hogy egy termék legyen egyedi, ugyanakkor stílusos és divatos is. Látható tehát, hogy vásárlásuk nagyrészt az egyes terméktulajdonságok (fizikai, esztétikai, szimbolikus) függvénye. A megkérdezettek válaszai alapján vásárlásuk történhet szükségletkielégítés céljából, de gyakran előfordul köreikben a kíváncsiságból történő, illetve érzelmi alapú-, impulzusvásárlás („vásárlás közben megtetszett”) is. Emellett magas azon válaszadók aránya is, akik tartósan érdekeltek, azaz hűségesen ragaszkodnak egy, a már jól bevált termékhez, ezért végül a következő alkalmakkor is a már saját preferenciáiknak megfelelt terméket emelik le a boltok polcairól.

A technika fejlődésével módszerek és eszközök jönnek-mennek a marketingben is. Régebben a szórólapozás, a hirdetések különböző újságok, 
magazinok hasábjain és - hosszú évtizedekig - a televízióban voltak a legelterjedtebb marketingkommunikációs eszközök, mára a webkorszakban már adaptálták az online felületeken is. Vannak azonban olyan eszközök, amelyek az érzékszervi marketing szerepéből kifolyólag - állandóan - ugyanolyan relevanciával vannak jelen, ezek a PoS és PoP-, illetve a vásárlásösztönző eszközök. Az általam válaszlehetőségként megadott, bizonyosvásárlásra késztető elemekhez kapcsolódóan érkezett válaszok a következők szerint alakultak (5. ábra).
Az ábrán jól látható, hogy a reklámok $(49,7 \%)$ és a társas kapcsolatok $(33,6 \%)$ szerepe relevánsabb az egyes marketingkommunikációs vásárlásösztönző eszközökénél; mivel legnagyobb arányban e két tényező ereje érvényesül vásárlásaik során.

Ezeket követi csak a kiegészítő előnyt biztosító, a termék mellé járó „filléres” ajándéktárgy (24\%), a nyerésre alapozott promóció $(12,8 \%)$ és a terméken szereplő mesefigura vagy híresség (10,5\%).

\section{5. ábra. A Tween korosztály vásárlását ösztönző tényezők} A vásárlást ösztönző tényező́k

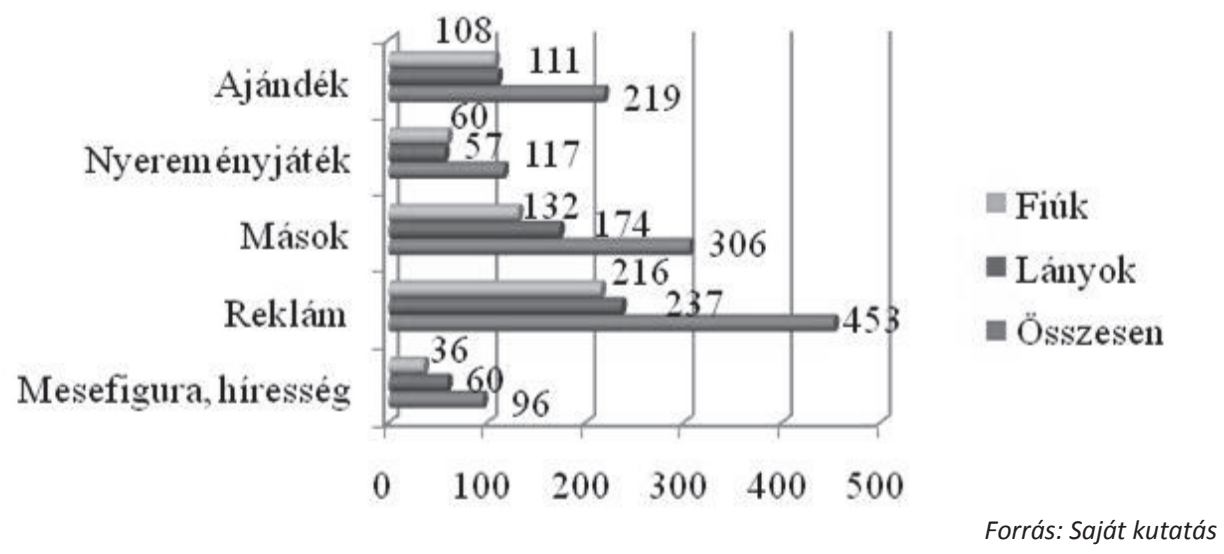

Utóbbi arányát különösen meglepőnek tartom, hiszen számos márkagyártó forgalmazza termékeit a gyerekek és fiatalok kedvenceivel, mint például a kettős életet élő Hannah Montana vagy Flash. Ez azzal magyarázható, hogy az általam megkérdezettek többsége (12 14 évesek) már „kinőtt” abból a korból, amelyben az emocionális kötődést erősítő merchandising hatékonynak bizonyul. Pusztán az ajándéktárgyak és a figurák esetében figyelhető meg némi különbség az egyes korcsoportok között - a fiatalabbak javára; azonban statisztikailag a Cramer's V értéke sem a nem, sem pedig a kor viszonylatában nem mutat szignifikáns kapcsolatot (Isd. XII-XIII. számú mellékletek).
A vizsgált korosztály fogyasztói magatartását befolyásoló tényezőihez kapcsolódó ismeretek kellő mélységének elérése érdekében kérdőívem 6 rövid, lényegre törő kérdésében arra kerestem a választ, hogy bizonyos exogén tényezők mennyire befolyásolják a megkérdezett 10-14 éves korosztályt, vagyis melyek azok, amelyek a leginkább befolyással bírnak fogyasztói magatartásuk felett.

Már az előző kérdésre érkezett válaszok esetében is jól látható volt, hogy a fiatalok a kortársakat és a reklámokat jelölte meg releváns, vásárlói magatartásukat befolyásoló külső tényezőként. Az elméleti fejezetben szerzett ismeretek fényében elmondható, hogy a kor előrehaladtával a generációk közötti 
kommunikációs szakadék mélyül, ezáltal a kortársak szerepe és egyben hatása erősödik fel. A fiatalok ebben a korban kezdenek társaikhoz igazodni, életmódjuk egymás összehasonlítási alapjaként szolgál. A válaszadók $36,2 \%$-át csúfolták már társai saját bevallása szerint, pusztán azért mert nem úgy öltözködik vagy nem olyan dolgokkal rendelkezik, mint társai. 912 főből 330 fő azért igen jelentős, ennek ellenére én a kiértékelés során ennél még magasabb arányra számítottam. Mindazonáltal elképzelhető, hogy a válasz esetében fennáll a torzítás lehetősége és a valóságban ez az arány valóban magasabb, csak esetlegesen szégyellték beismerni, noha a kérdőív kitöltése név nélküli volt. Ez a faktor azért fontos, mert extrinsik indítékot jelenthet a fiatalok vásárlása során (társadalmi elfogadás iránti igény, megfelelni akarás).

$A z$ ideális énkép és az ideális társadalmi énkép elérésére való törekvés ugyanis összefügg a termékek szimbolikus funkciójával. Többek között ennek okán válik fontossá a már szimbolikus tartalmú, emocionális fogyasztás, vagyis a vágyott énképek elérésére stílusos és trendi márkák fogyasztásával reagál a fiatal, hiszen ezáltal - a médiából sugárzott „értéknek” megfelelően - mások elismerése is könnyebben elnyerhető. Két, látszólag teljesen egyforma kérdésben arra kerestük a választ, hogy mennyiben igaz ez az általam megkérdezett fiatalokra.

Annak ellenére, hogy a vásárlásösztönzésre irányuló kérdésnél összesen 306 fő nyilatkozott úgy, hogy befolyásolja mások véleménye, a direkt megkérdezés esetén ez a szám 141 före (főként lányok) csökkent. Ez, az egyes válaszok összehasonlítása során nyert ellentmondásosság arról árulkodik, hogy ők magunk sincsenek teljesen tisztában a befolyás mértékével. Ugyanez a jelenség figyelhető meg a termékvásárlásra irányuló 5 fokozatú Likertskála esetében is, amely szúk 2,23-mas átlagértéket kapott (szórás: 0,935). A kor előrehaladtával egyértelműen kijelenthető, hogy a társak fogyasztása és termékválasztása rendre meghatározóbbá válik saját fogyasztói döntéseik során.

Így az általunk vizsgált 10-14 éves korosztály szimbolikus fogyasztására és a normatív csoportbefolyás összefüggésére vonatkozó feltételezés igazolást nyer. Eszerint érzékenységükből adódóan a megfelelni akarás kihat fogyasztói döntéseikre. Esetükben ezért a marketing - a média által - különösen a társadalmi nézetek, értékek, képek befolyásolásában kap fontos szerepet.

A valahová tartozás érzése mellett erre a mintakövetésre építenek fel tehát esetükben a reklámszakemberek egész stratégákat. Ehhez kapcsolódóan felmerül a kérdés, hogy mennyire eredményes az általam vizsgált iskolások esetében a reklámban - éppen a referenciacsoport hatásából eredően - a véleményvezetők alkalmazása. Kiindulópontnak és egyben viszonyítási alapnak hasznos a már megszerzett információ, hogy a legnagyobb arányban (külföldi) médiaszereplők inspirálják a megkérdezetteket. A válaszadók túlnyomó többségét $(76,6 \%)$ állítása szerint nem befolyásolja egy termék közismert személlyel történő reklámozása. Ez - ismerve a tényt, hogy ugyanezen embereket saját példaképeik egyben - nagymértékű racionalitást feltételez, hiszen lévén számukra véleményvezérek ezek a személyek, szeretnének hozzájuk hasonlítani, azonban nem hisznek el mindent. Ezenkívül ez a $76,6 \%$-os érték magyarázható azzal is, hogy jellemzően az idősebb korosztály tagjai választják őket példaképüknek és minél idősebbek és érettebbé válik a személyiségük, annál kevésbé van szükségük követésükre, egyszerűen csak felnéznek rájuk, mint egy igazodási pontra.

Napjainkban az internet térhódításával a televízió még mindig hűen őrzi tömegmédium nagyhatalmát, tehát könnyen és nagy célközönség érhető el általa. A hagyományos értelemben vett televíziós reklámok, azaz a reklámszpotok jelentősége a fogyasztók tudatos ellenállásával a befolyási kísérletnek elméletben halványulni látszik, ezért a szpotok 
mellett egyéb marketingkommunikációs eszközök kerülnek előtérbe, mint például a product placement. Arról kérdeztük a gyerekeket, hogy vettek-e már igénybe olyan szolgáltatást, amelyet a reklámban vagy egyéb músorban felismertek és az meggyőzte őket arról, hogy próbálják ki ők is. A válaszadók $28 \%$ a szerint soha nem fordult még elő, hogy kipróbáltak volna ezért szolgáltatást. 30,3 százalékuk beismerte ugyan, hogy volt már rá példa, de nem a közelmúltban. A tanulók csupán 6,6 százaléka nyilatkozta, hogy gyakran vesz igénybe televízióban reklámozott szolgáltatást. Ez alapján kijelenthető, hogy a szolgáltatások esetében a reklámbefolyás irreleváns.

Ehhez kapcsolódóan egy másik kérdésben a televiziós reklámok eredményességét a termékvásárlás függvényében vizsgáltuk. Az iskolásoknak 1-5-ig terjedő skálán kellett kiválasztani a rá jellemző értéket aszerint, hogy milyen gyakran fordul elő az, hogy a televízióban aktuálisan reklámozott termékből vagy szolgáltatásból vásárol. A beérkezett válaszokat az alábbi ábra szemlélteti:

\section{6. ábra. A megkérdezettek televíziós reklám hatására történő termékvásárlása}

Gyakran vásárolok televízióban reklámozott terméket

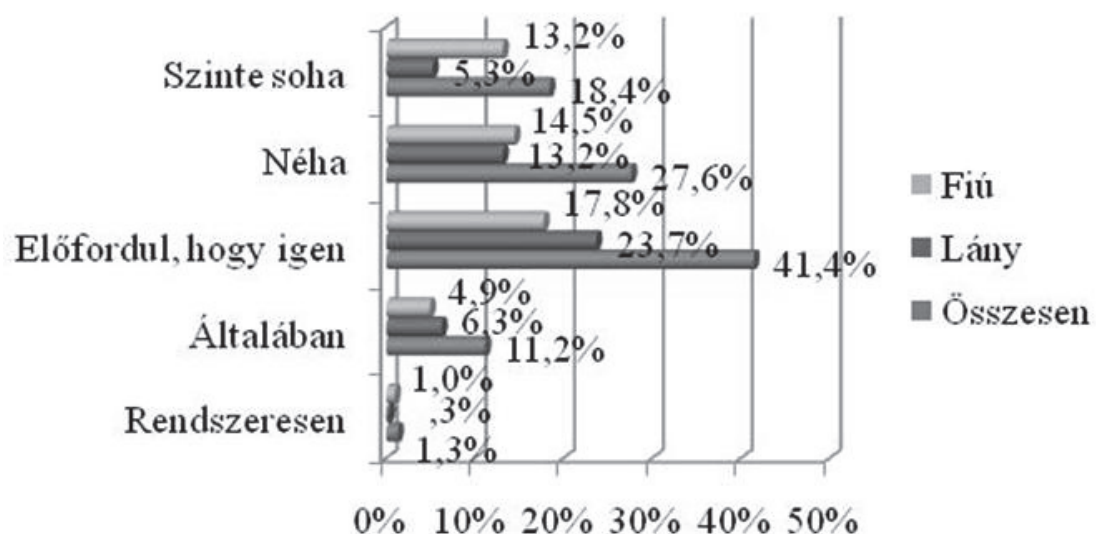

Forrás: Saját kutatás
Általánosságban elmondható, hogy a válaszadókat az egyes korcsoportonként nem jellemezte erőteljes megosztottság. 41,4 százalékuk ismerte be, hogy előfordul, hogy vásárol a televízióban reklámozott termékből vagy szolgáltatásból, tehát a szakirodalomban megismert, a fiatalokat általánosságban jellemző reklámkerülő magatartás ellenére is rendelkeznek befolyással felettük. A 6. ábráról jól leolvasható, hogy a lányok nagyobb hajlandóságot mutatnak fiútársaikhoz képest arra, hogy kísérletezzenek a televízióban reklámozott termékekkel - még annak ellenére is, hogy a kapcsolat szorosságát vizsgáló Cramer mutató értéke $(V=0,217)$ gyenge kapcsolatra utal a megkérdezettek neme és a reklám eredményezte vásárlás között (Isd. bővebben XV. számú melléklet).

A termékvásárláshoz kapcsolódóan fontosnak tartottuk azt is megvizsgálni, hogy milyen témájú televíziós reklámokat tart érdemesnek arra az általunk megkérdezett 10-14 éves korosztály, hogy megtekintsék azokat; vagyis mely tévéreklámok azok, amelyek üzenete a legkönnyebben célba ér. A leggyakoribb válaszokat foglalja magában a 7. ábra.

$\mathrm{Az}$ ábrán jól látható, hogy a válaszadók leggyakrabban az elektronikai cikkek reklámjait 
(70,7\%) nézik végig - kortól és nemtől függetlenül. Ezt követik a cipő és ruházati termékek (54,6\%), a sporttal kapcsolatos témájú reklámok (52,6\%), a filmelőzetesek vagy játékok- (30,9\%), illetve édességek reklámjai. Vizsgálva, hogy van-e kapcsolat az egyes reklámkategóriák és a nemek között, a kapcsolat szorosságát mutató Cramer's V értéke pusztán a cipő-ruházat $(V=0,399)$, illetve a szépségápolási termékek $(V=0,380)$ reklámjai esetében mutattak közel közepes erősségú kapcsolatot. Ahogyan azt már a termékvásárlás esetében észrevételeztük, most a „reklámfogyasztás” estében is megfigyelhető, hogy mind a fiúk, mint a lányok figyelmét elsősorban saját nemi szerepeikhez kötődő reklámok keltik fel. Mivel a kor elörehaladtával a lányok egyre több figyelmet fordítanak megjelenésükre, ápoltságukra, bimbózó nőiességükre, ezért ők elsősorban a külsejükkel, kinézetükkel kapcsolatos tartalmakat keresik, a fiúk pedig jellemzően a sport és az élelmiszerreklámok felé fordulnak. A Cramer's V értékei alapján a többi tényező esetében nincs szignifikáns kapcsolat, ahogyan az egyes korcsoportok esetében sem figyelhetők meg éles különbségek.

\section{7. ábra. Leggyakrabban megtekintett reklámkategóriák} Megtekintett reklámkategóriák

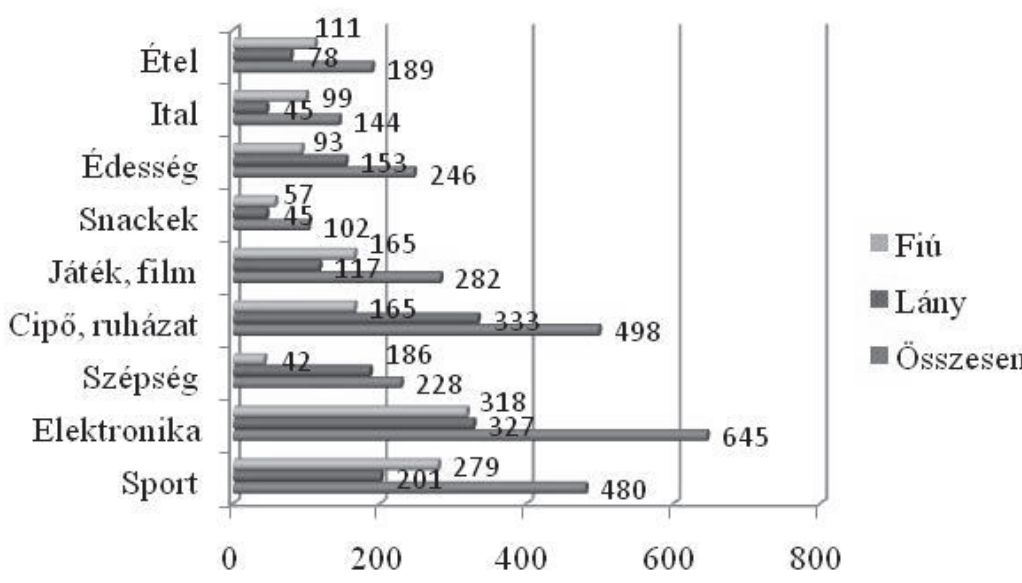

Forrás: Saját kutatás

\section{4. ÖSSZEFOGLALÁS}

Jelen munkánkban bemutattuk a Z generáció világát, vásárlásösztönző eszközökön keresztül és márkakapcsolással igyekeztünk egy átfogó képet nyújtani az egyes belső és külsőfogyasztói magatartásukat befolyásolótényezőkről, ezek elemzésével. Kvantitatív kutatásunk alátámasztja, hogy a netgenerációs nemzedék preferenciái, attitűdjei még folyamatosan változnak, különféle hatásokra reagálva formálódnak, alakulnak. Erőteljes megosztottság jellemzi őket is és szokásaikat is, értékrendjük, szemléletmódjuk új és izgalmas. A fiatalok piaca tehát egy gyorsan egy gyorsan változó piac, ahol a fragmentálódás természetes jelenség, ezért annak érdekében, hogy a vállalatok lépést tartsanak folyamatosan változó igényeikkel, megfeleljenek elvárásaiknak, esetükben rugalmas és differenciált marketingstratégia kidolgozása lehet csak célravezető. 


\section{FELHASZNÁLT IRODALOM}

[1.] Cole, M. \& Cole, S. R. (2003) Fejlődéslélektan. Budapest: Osiris Kiadó, pp. 397-407

[2.] Crowley, A. \& DeJong-Boots, D., Paladines, M. (2014) 'What's a tween?' Homepage of Tween programming [Online] Letöltés dátuma: 2014.11.11. http://courseweb.lis.illinois.edu/ crowley8/506tweens/Tween_Programming/Home.html

[3.] http://net.jogtar.hu/jr/gen/hjegy_doc.cgi?docid=A0800048.TV

[4.] Letöltés dátuma: 2015.01.23.

[5.] Piacentini, M, \& Mailer, G. (2004) 'Symbolic consumption in teenagers' clothing choices' Journal of Consumer Behaviour, 3 (3), pp. 251-262

[6.] Reklámtörvény (2008) '2008. évi XLVIII. törvény a gazdasági reklámtevékenység alapvető feltételeiről és egyes korlátairól' Jogtár [Online]

[7.] Szűcs R. S. (2011) '„Egészségtelen” élelmiszerek attitűdvizsgálata a fiatalok szegmensében' Marketing \& Menedzsment, 45 (2), pp. 60-66

[8.] Törőcsik M. (2007) Vásárlói magatartás. Budapest: Akadémiai Kiadó, pp. 13-32, 46-82 
